This article was downloaded by: [Isfahan University of Technology]

On: 1 March 2009

Access details: Access Details: [subscription number 907377393]

Publisher Taylor \& Francis

Informa Ltd Registered in England and Wales Registered Number: 1072954 Registered office: Mortimer House, 37-41 Mortimer Street, London W1T 3JH, UK

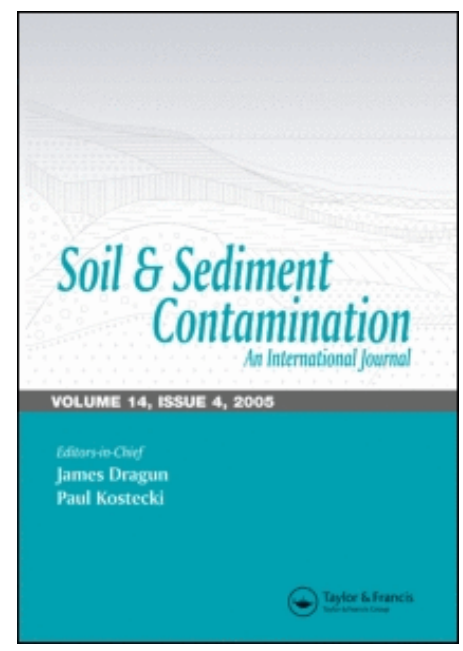

Soil and Sediment Contamination: An International Journal

Publication details, including instructions for authors and subscription information: http://www.informaworld.com/smpp/title content=t713401148

\title{
Effects of Cadmium, Copper, Lead, and Zinc Contamination on Metal Accumulation by Safflower and Wheat
}

Gholamabbas Sayyad a; Majid Afyuni ${ }^{\text {b; }}$ Sayed-Farhad Mousavi c; Karim C. Abbaspour d; Mohammad A. Hajabbasi ${ }^{\mathrm{b}}$; Brian K. Richards ${ }^{\mathrm{e}}$; Rainer Schulin ${ }^{\mathrm{f}}$

${ }^{a}$ College of Agriculture, Shahid Chamran University of Ahvaz, Ahvaz, Iran b College of Agriculture, Department of Soil Science, Isfahan University of Technology, Isfahan, Iran ${ }^{\circ}$ College of Agriculture, Department of Irrigation, Isfahan University of Technology, Isfahan, Iran ${ }^{d}$ Swiss Federal Institute for Environmental Science and Technology, EAWAG, Dübendorf, Switzerland ${ }^{\circ}$ Department of Biological and Environmental Engineering, Cornell University, Ithaca, NY, USA ${ }^{f}$ Institute of Terrestrial Ecology ETH Zürich, Zürich, Switzerland

Online Publication Date: 01 March 2009

To cite this Article Sayyad, Gholamabbas, Afyuni, Majid, Mousavi, Sayed-Farhad, Abbaspour, Karim C., Hajabbasi, Mohammad A., Richards, Brian K. and Schulin, Rainer(2009)'Effects of Cadmium, Copper, Lead, and Zinc Contamination on Metal Accumulation by Safflower and Wheat',Soil and Sediment Contamination: An International Journal, 18:2,216 - 228

To link to this Article: DOI: $10.1080 / 15320380802660248$

URL: http://dx.doi.org/10.1080/15320380802660248

\section{PLEASE SCROLL DOWN FOR ARTICLE}

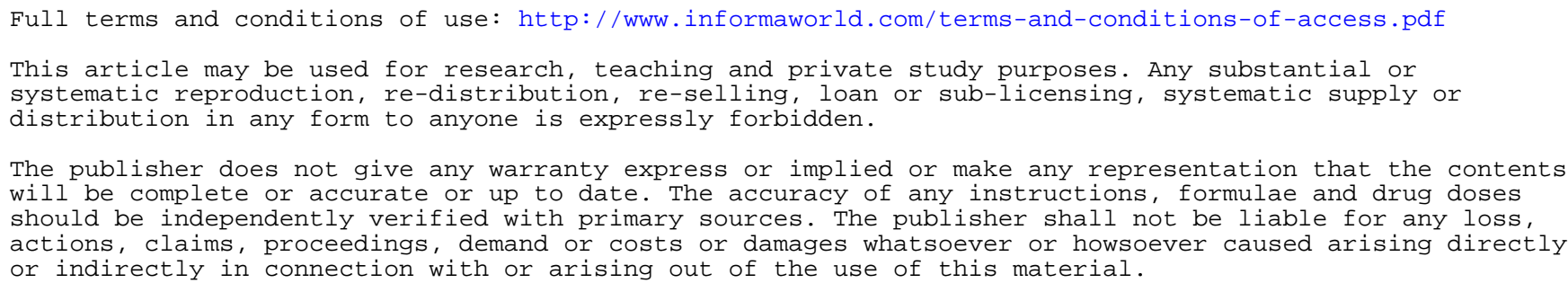

The publisher does not give any warranty express or implied or make any representation that the contents will be complete or accurate or up to date. The accuracy of any instructions, formulae and drug doses should be independently verified with primary sources. The publisher shall not be liable for any loss, actions, claims, proceedings, demand or costs or damages whatsoever or howsoever caused arising directly or indirectly in connection with or arising out of the use of this material. 


\title{
Effects of Cadmium, Copper, Lead, and Zinc Contamination on Metal Accumulation by Safflower and Wheat
}

\author{
GHOLAMABBAS SAYYAD, ${ }^{1}$ MAJID AFYUNI, ${ }^{2}$ \\ SAYED-FARHAD MOUSAVI, ${ }^{3}$ KARIM C. ABBASPOUR, ${ }^{4}$ \\ MOHAMMAD A. HAJABBASI, ${ }^{2}$ BRIAN K. RICHARDS, ${ }^{5}$ \\ AND RAINER SCHULIN ${ }^{6}$ \\ ${ }^{1}$ College of Agriculture, Shahid Chamran University of Ahvaz, Ahvaz, Iran \\ ${ }^{2}$ College of Agriculture, Department of Soil Science, Isfahan University of \\ Technology, Isfahan, Iran \\ ${ }^{3}$ College of Agriculture, Department of Irrigation, Isfahan University of \\ Technology, Isfahan, Iran \\ ${ }^{4}$ Swiss Federal Institute for Environmental Science and Technology, EAWAG, \\ Dübendorf, Switzerland \\ ${ }^{5}$ Department of Biological and Environmental Engineering, Cornell University, \\ Ithaca, NY, USA \\ ${ }^{6}$ Institute of Terrestrial Ecology ETH Zürich, Zürich, Switzerland
}

\begin{abstract}
Accumulation of heavy metals (HMs) in cultivated soils is a continuing environmental problem in many parts of the world. An increase in HM concentration can enhance uptake of toxic metals by crops and enter the human food chain. In this study, the uptake behavior of wheat and safflower was evaluated in a calcareous soil by using 12 undisturbed columns in which half were artificially contaminated. Heavy metals in the form of $\mathrm{CdCl}_{2}\left(15 \mathrm{mg} \mathrm{Cd} \mathrm{kg}^{-1}\right), \mathrm{CuSO}_{4}\left(585 \mathrm{mg} \mathrm{Cu} \mathrm{kg}^{-1}\right), \mathrm{Pb}\left(\mathrm{NO}_{3}\right)_{2}\left(117 \mathrm{mg} \mathrm{Pb} \mathrm{kg}^{-1}\right)$, and $\mathrm{ZnCl}_{2}\left(1094 \mathrm{mg} \mathrm{Zn} \mathrm{kg} \mathrm{g}^{-1}\right)$ were sprayed on the soil surface and completely mixed in the top $10 \mathrm{~cm}$. The background total concentrations of $\mathrm{Cd}, \mathrm{Cu}, \mathrm{Pb}$ and $\mathrm{Zn}$ were 1.6, $29.5,17.5$ and $61.2 \mathrm{mg} \mathrm{kg}^{-1}$, respectively. After metal application, half of the columns (3 contaminated and 3 uncontaminated) were sown with wheat (Triticum aestivum) and the other half with safflower (Carthamus tinctorious) and grown for 74 days until maturity. After harvesting, soil columns were cut into 10-cm sections and analyzed for $\mathrm{HNO}_{3}$ - and DTPA-extractable metal concentrations. Metal concentrations were also measured in different plant tissues. The results showed that artificial contamination of topsoil decreased the transpiration rate of wheat by $12 \%$ and that of safflower by $6 \%$. In contaminated columns, $\mathrm{Cd}, \mathrm{Cu}, \mathrm{Pb}$, and $\mathrm{Zn}$ accumulation in wheat shoot was greater by 8.0-, 1.9-, 3.0-, and 2.1-fold than the control, respectively. Accordingly, these numbers were 46.0-, 1.3-, 1.7-, and 1.6-fold in safflower shoot. Soil contamination with HMs resulted in a 55\% decrease in shoot dry matter yield of wheat while it had no significant effect on shoot dry matter of safflower. The normalized water consumption for safflower was therefore not affected by metal contamination $\left(\approx 13 \mathrm{~mm} \mathrm{H}_{2} \mathrm{O} \mathrm{g} \mathrm{g}^{-1}\right.$ of dry weight for all safflower and uncontaminated wheat treatments), while contaminated wheat was
\end{abstract}

Address correspondence to Gholamabbas Sayyad, Assistant Professor, Department of Soil Science, College of Agriculture, Shahid Chamran University of Ahvaz, Ahvaz, Iran. E-mail: gsayyad@gmail.com 
much less water efficient at about $27 \mathrm{~mm} \mathrm{H}_{2} \mathrm{O} \mathrm{g}^{-1}$ dry weight. It was concluded that although artificial contamination had a negative effect on wheat growth, it did not affect safflower's normal growth and water efficiency.

Keywords Metal accumulation, evapotranspiration, heavy metals, calcareous soil

\section{Introduction}

Accumulation of heavy metals (HMs) in cultivated soils is a continuing environmental problem in many parts of the world (Higgins, 1984; Hinz and Selim, 1994; McBride et al., 1997; Richards et al., 1998; Li and Li, 2001; Schwab et al., 2002). Elevated HM concentrations in the soil can lead to enhanced crop accumulation (Street et al., 1977; van Lune and Zwart, 1997; Santa-Maria and Cogliatti, 1998; Gerard et al., 2000; Obrador et al., 2003). Plants are an important link in the pathway by which excessive amounts of HM are channelled into the food chain and biological cycles (Wierzbicka and Obidzinska, 1998). Excessive metals in human nutrition could be toxic and cause acute and chronic diseases. For example, $\mathrm{Cd}$ and $\mathrm{Zn}$ can cause acute gastrointestinal, respiratory, heart, brain and kidney damage (Wagner, 1993; Schmidt, 2003). Lead may cause nephrotoxicity, neurotoxicity, and hypertension as well as skeletal problems in children (WRCD, 1996). The transfer of HMs from soils to plants depends on three factors: the total concentration (quantity factor), the bioavailability of elements in the soil solution (intensity factor), and the rate of element transfer from solid to liquid phases and to plant roots (Schmidt, 2003).

Heavy metal stress causes direct and indirect effects on physiological processes in plants. The primary toxicity mechanisms of HMs alter the catalytic function of enzymes (van Assche and Clijsters, 1988), and damage cellular membranes (Kastori et al., 1992). These changes may cause numerous secondary effects, such as inhibition of photosynthesis (Clijsters et al., 1999), mineral nutrient accumulation (Kastori et al., 1992), root and shoot growth (Ewais, 1997), and mineralization (Aoyama and Kuroyanagi, 1996), as well as hormonal imbalance and water stress (Kastori et al., 1992; Prasad, 1995). Up to now, great attention has been paid to the effects of HM stresses on photosynthesis and mineral nutrition, rather than water relations in soil-plant systems. However, a decrease in stomatal conductance and transpiration rate (Sheoran et al., 1990) has been observed by many researchers.

In the calcareous soils of Isfahan in central Iran, industrial and agricultural HM contamination is a concern (Amini et al., 2005). Wheat (Triticum aestivum) is the major crop in the region, and safflower (Carthamus tinctorious) is a popular oil crop due to its tolerance of salinity and drought (Bassil and Kaffka, 2002). Wheat has a fibrous root but safflower has a taproot, which could cause differences in metal accumulation by these two rooting systems. The objectives of this study were to evaluate the effects of elevated concentrations of $\mathrm{Cd}$, $\mathrm{Cu}, \mathrm{Pb}$ and $\mathrm{Zn}$ on their accumulation and biomass of wheat and safflower in a calcareous soil.

\section{Materials and Methods}

A greenhouse experiment was conducted using 12 initially undisturbed soil columns $(22.5 \mathrm{~cm}$ in diameter and $50 \mathrm{~cm}$ in depth). A calcareous soil (Fine, Mixed, Termic, Typic Haplocalcid (Soil Survey Staff, 2003)) was sampled on two nearby fields from Kabotarabad Research Station of Isfahan Agricultural Research Center, $40 \mathrm{~km}$ southeast of Isfahan, central Iran (3598500N, 572000E, UTM, Zone 39). The mean annual precipitation 
Table 1

Average and standard deviations of soil chemical and physical properties*

\begin{tabular}{lccc}
\hline Soil properties & \multicolumn{3}{c}{ Depth $(\mathrm{m})$} \\
\hline & $0-0.25$ & $0.25-0.45$ & $0.45-0.60$ \\
$\mathrm{pH}$ & $7.6 \pm 0.1$ & $7.7 \pm 0.1$ & $7.8 \pm 0.1$ \\
$\mathrm{EC}(\mathrm{dS} / \mathrm{m})$ & $9.8 \pm 1.6$ & $7.8 \pm 1.9$ & $5.9 \pm 2.2$ \\
$\mathrm{CaCO}(\%)$ & $37.2 \pm 1.7$ & $35.9 \pm 0.5$ & $36.2 \pm 1.4$ \\
$\mathrm{~N}(\%)$ & $0.04 \pm 0.01$ & $0.04 \pm 0.01$ & $0.03 \pm 0.01$ \\
$\mathrm{P}(\mathrm{mg} / \mathrm{kg})$ & $25.1 \pm 3.1$ & $20.0 \pm 3.2$ & $18.0 \pm 2.3$ \\
$\mathrm{Cd}(\mathrm{mg} / \mathrm{kg})$ & $1.6 \pm 0.5$ & $1.7 \pm 0.3$ & $1.6 \pm 0.5$ \\
$\mathrm{Cu}(\mathrm{mg} / \mathrm{kg})$ & $31.0 \pm 1.9$ & $29.5 \pm 1.6$ & $28.1 \pm 1.6$ \\
$\mathrm{~Pb}(\mathrm{mg} / \mathrm{kg})$ & $19.3 \pm 1.5$ & $19.1 \pm 1.9$ & $14.1 \pm 2.1$ \\
$\mathrm{Zn}(\mathrm{mg} / \mathrm{kg})$ & $64.3 \pm 5.5$ & $62.1 \pm 5.1$ & $57.3 \pm 3.2$ \\
$\mathrm{Cl}(\%)$ & $2.1 \pm 0.5$ & $1.6 \pm 0.3$ & $1.1 \pm 0.2$ \\
$\mathrm{CEC}(\mathrm{cmol} / \mathrm{kg})$ & $13.8 \pm 0.7$ & $14.6 \pm 0.5$ & $14.3 \pm 0.8$ \\
Organic $\mathrm{matter}(\mathrm{g} / \mathrm{kg})$ & $8.0 \pm 0.3$ & $7.0 \pm 0.8$ & $5.0 \pm 0.3$ \\
Sand $(\mathrm{g} / \mathrm{kg})$ & $179.0 \pm 15.2$ & $171.0 \pm 11.2$ & $182.0 \pm 5.1$ \\
Silt $(\mathrm{g} / \mathrm{kg})$ & $432.0 \pm 21.2$ & $424.0 \pm 12.1$ & $433.0 \pm 22.0$ \\
$\mathrm{Clay}(\mathrm{g} / \mathrm{kg})$ & $390.0 \pm 23.0$ & $405.0 \pm 31.0$ & $384.0 \pm 12.0$ \\
$\mathrm{Bulk} \mathrm{density}\left(\mathrm{Mg} / \mathrm{m}^{3}\right)$ & $1.32 \pm 0.2$ & $1.4 \pm 0.1$ & $1.43 \pm 0.1$ \\
\hline
\end{tabular}

*Average of three replications \pm standard deviation.

is $145 \mathrm{~mm}$. One field had been cultivated with safflower and the other with wheat in the previous year. The crop rotation on the wheat field was wheat-fallow-wheat-wheat and wheat-wheat-fallow-safflower on the safflower field in the four years before sampling.

Disturbed soil samples were taken from different depths in the field. Soil samples were air dried, crushed and sieved to $<2 \mathrm{~mm}$. The $\mathrm{pH}$ was measured in saturated paste using a pH-meter (Model Metrohm 320), electrical conductivity (EC) in saturated paste extract by EC-meter (Model Metrohm 644), and calcium carbonate by titration with $\mathrm{NaOH}$. Cadmium, $\mathrm{Cu}, \mathrm{Pb}$ and $\mathrm{Zn}$ were extracted by $4 \mathrm{M} \mathrm{HNO}_{3}$ (Sposito et al., 1981) and measured using AAS, (SpectraAA 220/FS, Varian, Australia). Chloride was determined by titration with $\mathrm{AgNO}_{3}$, cation exchange capacity (CEC) by $\mathrm{CH}_{3} \mathrm{COONa}$ method (Sumner and Miller, 1996), organic mater (OM) by using wet oxidation method (Walkley and Black, 1934), soil particle analysis (sand, silt and clay) by hydrometer method (Gee and Bauder, 1986), and bulk density by soil cores (Blake and Hartge, 1986).

A randomized complete block design with three replications was conducted. Twelve undisturbed soil columns $(22.5 \mathrm{~cm}$ diameter, $50 \mathrm{~cm}$ depth) were sampled. For preparing undisturbed soil columns, two parallel long trenches were dug and the columns were carefully excavated by removing the surrounding soil. The polyethylene tubes were driven (by pressure) into the soil to a depth of $50 \mathrm{~cm}$. Each column was placed on a support and the leachate was collected through a plastic funnel to determine water balance and calculate ET.

The columns were divided into two groups. In the first group, solutions of $\mathrm{CdCl}_{2}(15 \mathrm{mg}$ $\left.\mathrm{Cd} \mathrm{kg}^{-1}\right), \mathrm{CuSO}_{4}\left(585 \mathrm{mg} \mathrm{Cu} \mathrm{kg}^{-1}\right), \mathrm{Pb}\left(\mathrm{NO}_{3}\right)_{2}\left(117 \mathrm{mg} \mathrm{Pb} \mathrm{kg}^{-1}\right)$, and $\mathrm{ZnCl}_{2}(1094 \mathrm{mg} \mathrm{Zn}$ $\mathrm{kg}^{-1}$ ) were separately sprayed on the soil surface and completely mixed with the top $10 \mathrm{~cm}$ using a plastic shovel. Total applied amounts of $\mathrm{Cd}, \mathrm{Cu}, \mathrm{Pb}$ and $\mathrm{Zn}$ were 77.5, 2980.6, 596.1 
and $5563.7 \mathrm{mg}$ column ${ }^{-1}$, respectively. The remaining columns were left uncontaminated. The amounts of metals added to the soil were chosen based on $50 \%$ of maximum permitted metal loadings in soil established by USEPA Part 503 regulations (USEPA, 1993). During two weeks after metal application, for normal plant growth, the columns were irrigated until discharge EC decreased around $2 \mathrm{dS} \mathrm{m}^{-1}$. Thereafter, independent of contamination, $60 \mathrm{mg} \mathrm{N} \mathrm{kg}^{-1}$ as urea and $40 \mathrm{mg} \mathrm{K} \mathrm{kg}^{-1}$ as potassium nitrate were mixed to the top soil. Although due to $\mathrm{Pb}\left(\mathrm{NO}_{3}\right)_{2}$ application topsoil $\mathrm{N}$ concentrations in contaminated columns were more than controls by about $15 \mathrm{mg} \mathrm{N} \mathrm{kg}^{-1}$, it is still very low compared to the background soil total $\mathrm{N}$ concentration (Table 1) plus applied $65 \mathrm{mg} \mathrm{N} \mathrm{kg}^{-1}$ in the form of urea and potassium nitrate. Furthermore, after irrigations (applied during the two weeks before fertilizing), $\mathrm{NO}_{3}$ leaching from the soil columns (data not shown) sharply decreased the difference in $\mathrm{N}$ concentration of the columns. In any case, soil conditions were the same for both plants justifying their comparison. As the soil native phosphorus concentration (Table 1) was sufficient for plant growth, we did not add any P-fertilizer. Thereafter, half of the columns were sown with a spring variety of wheat (Mahdavi) (200 seeds $\mathrm{m}^{-2}$ ) and the others with a cultivar of safflower (Kose) $\left(20\right.$ seeds $\left.\mathrm{m}^{-2}\right)$. The same was done for uncontaminated columns. Columns were irrigated using tap water, which was used in order to be as close as possible to realistic farm conditions, wherein farmers use river water for irrigation. Tap water also was used in some other experiments (Frost and Ketchum, 2000; Liu et al., 2003). The analyses showed that there is no metal in the applied tap water. The irrigation was based on $65 \%$ depletion of the available soil water capacity. For this purpose, soil moisture characteristic curves were determined at 10, 30, 50, 100, 300, 500, 1000 and $1500 \mathrm{kPa}$ (Klute, 1986).

Water content in the columns was measured using horizontal TDR probes (6050X1 Trase System, soil moisture, USA) placed at 15, 30 and $45 \mathrm{~cm}$ depths. Leachate was continuously collected and its volume and concentration of metals (data not shown) were measured to determine water balance and calculate ET.

Plants were harvested by cutting the shoots at the end of pollination (74 days after sowing). Safflower matured about a week sooner than wheat. Plant samples were washed carefully with tap water to remove dust and rinsed with $0.1 \mathrm{M} \mathrm{HCl}$ solution followed by several rinses with deionized water. The samples were then oven dried at $60^{\circ} \mathrm{C}$ and ground in a mill. The roots and shoots (stems plus leaves) and heads (spike in wheat and head in safflower) were analyzed separately. Sub-samples of $0.2 \mathrm{~g}$ were digested in 6 $\mathrm{mL}$ of $65 \% \mathrm{HNO}_{3}, 2 \mathrm{~mL}$ of $2 \% \mathrm{H}_{2} \mathrm{O}_{2}$ and $2 \mathrm{~mL}$ of distilled water, and heated at $100^{\circ} \mathrm{C}$ for 25 minutes in microwave (MSL-1200 with HPV 80, pressure digestion vessels AGW, Leutkirch, Germany). The solution was then filtered using Whatman No. 42 filter paper and analyzed by graphite furnace atomic absorption spectrometry (Varian Spectra 300-400, Varian, Australia).

After harvesting the plants, soil columns were cut into $10-\mathrm{cm}$ sections, air dried, crushed by a woody hammer, and sieved to $<2 \mathrm{~mm}$ by a $2 \mathrm{~mm}$ stainless steel sieve. Sub-samples were collected from each section and analyzed for $\mathrm{HNO}_{3}$ - (Sposito et al., 1981) and DTPA-extractable metal concentrations (Soltanpour et al., 1991). A mixture of $9.6 \mathrm{~g}$ soil and $60 \mathrm{~mL}$ of $4 \mathrm{M} \mathrm{HNO}_{3}$ was heated overnight at $70^{\circ} \mathrm{C}$ on a hot plate. The mixture was subsequently centrifuged for 15 minutes and filtered using Whatman No. 42 filter paper. DTPA-metals were extracted by shaking $20 \mathrm{~g}$ soil and $40 \mathrm{~mL}$ DTPA solution (a mixture of $1 \mathrm{M} \mathrm{NH}_{4} \mathrm{HCO}_{3}$ and $0.005 \mathrm{M}$ DTPA buffered at $\mathrm{pH}$ 7.6) for 15 minutes and filtered. Total heavy metal accumulation in soil can be monitored through acid (e.g., $\mathrm{HNO}_{3}$ ) soil extractions. Evaluation of total metal levels may be useful as a global index 
of contamination, but it provides little indication of their specific bioavailability, mobility, and reactivity in soils (Cao et al., 1984; Walter et al., 2002). Another monitoring approach consists of the use of various chemical reagents to estimate the fraction of the soil metal that is potentially available to plants. The most frequently employed reagents are chelating agents such as DTPA. Metals extracted by DTPA largely exist in exchangeable, organically complexed and carbonate forms. Such extraction provides more information about metal availability and tends to correlate with metal uptake by plants (Hooda and Alloway, 1994). The absolute quantity of metals extracted by DTPA is a useful means of evaluating plantavailable metals in the soil (Walter et al., 2002). In this study both methods were used and the results were related to the metal concentrations in plants and compared. The metal concentrations in the extracts were analyzed using atomic absorption spectrometry $(\mathrm{Zn}, \mathrm{Cu})$ (AAS, SpectraAA 220/FS, Varian, Australia) or inductively coupled plasma (Cd, Pb) (ICPOES, Vista-MPX Varian, Australia). Quality control samples included Standard Reference Materials BCR number 62 (Olive Leaves) and number 962 sandy clay from the Netherlands. Good agreements were achieved between the data obtained and the certified values.

The water balance for the whole experiment period was calculated using the following expression:

$$
\mathrm{ET}=\mathrm{I}-\mathrm{D}+\Delta \mathrm{S}
$$

where ET is actual evapotranspiration $(\mathrm{mm}), \mathrm{I}$ is irrigation $(\mathrm{mm}), \mathrm{D}$ is discharge $(\mathrm{mm})$, and $\Delta S$ is the change in column's moisture storage $(\mathrm{mm})$. The change in storage $\Delta S$ was determined by the difference in total water at two time points (the first at the beginning of the experiment, the second at the end). For calculating total water content, the measured volumetric water content $\left(\mathrm{cm}^{3} \mathrm{~cm}^{-3}\right)$ in unit area $\left(\mathrm{cm}\right.$ water $\mathrm{cm}^{-1}$ soil) in each depth was multiplied by the respective soil depth $(\mathrm{cm})$, resulting in water depth; the summation of water depths in three depth zones resulted in total water content in the column. In this calculation, the TDR at the $15-\mathrm{cm}$ depth was assumed to represent the water content in the depth of $0-20 \mathrm{~cm}$, and the TDRs at 30 and $45-\mathrm{cm}$ depths were assumed to represent intervals of $20-40 \mathrm{~cm}$ and $40-50 \mathrm{~cm}$, respectively.

To evaluate the effect of contamination on plant growth, water use efficiency (dry biomass/water used (ET)) of both plants in different treatments was calculated and compared.

Statistical studies were conducted with SAS software (Version 6.12). Multiple comparisons of variables were made by using LSD's separation of means procedure. A probability level of $\mathrm{P} \leq 0.05$ was chosen to establish statistical significance.

\section{Results and Discussion}

\subsection{Soil Properties}

Chemical and physical properties of the soils under wheat and safflower in the field showed small differences, so the average values of the two farms are shown in Table 1. We intended to have similar soil profiles so as to reveal the differences in the two different rooting systems.

The calcareous soil had a high cation exchange capacity (CEC) and high pH (Table 1), with an organic matter content of less than $1 \%$. A large amount of $\mathrm{CaCO}_{3}$ imparts large buffering capacity for $\mathrm{pH}$, which in general decreases the possibility of metal solubility (Plassard et al., 2000). But the dominant anion, chloride, can form soluble complexes 
Table 2

Effect of contamination on evapotranspiration and dry biomass $*$ (average \pm standard deviation)

\begin{tabular}{|c|c|c|c|c|}
\hline Treatment & $\begin{array}{c}\text { Soil water } \\
\text { storage change } \\
(\mathrm{mm})\end{array}$ & $\begin{array}{c}\mathrm{ET}^{\dagger} \\
(\mathrm{mm})\end{array}$ & $\begin{array}{l}\text { Discharge } \\
(\mathrm{mm})\end{array}$ & $\begin{array}{l}\text { Aerial dry biomass } \\
\text { (g plant/column) }\end{array}$ \\
\hline $\mathrm{W}^{\dagger \dagger}$ & $-12.7 \pm 5.1^{a \S}$ & $382.0 \pm 3.7^{a b}$ & $193.0 \pm 8.8^{b}$ & $27.6 \pm 7.1^{a}$ \\
\hline $\mathrm{W}+\mathrm{M}$ & $-7.0 \pm 5.7^{b}$ & $336.0 \pm 20.2^{c}$ & $245.0 \pm 14.3^{a}$ & $12.4 \pm 3.2^{b}$ \\
\hline $\mathrm{S}$ & $-17.0 \pm 8.4^{a}$ & $391.0 \pm 11.4^{a}$ & $180.0 \pm 19.8^{b}$ & $29.8 \pm 2.4^{a}$ \\
\hline $\mathrm{S}+\mathrm{M}$ & $-9.0 \pm 7.0^{b}$ & $367.0 \pm 5.9^{b c}$ & $212.0 \pm 12.9^{a b}$ & $27.4 \pm 4.9^{a}$ \\
\hline
\end{tabular}

with Cd (Smolders and McLaughlin, 1996; Khoshgoftar et al., 2004) that may increase its solubility.

Background metal concentrations in soil profiles showed that the soil was not polluted (Table 1). The order of metal concentration in soil profile were $\mathrm{Zn}>\mathrm{Cu}>\mathrm{Pb}>\mathrm{Cd}$. Average total concentrations of $\mathrm{Cd}, \mathrm{Cu}, \mathrm{Pb}$ and $\mathrm{Zn}$ were $1.6,29.5,17.5$ and $61.2 \mathrm{mg} \mathrm{kg}^{-1}$, respectively, which are lower than the maximum acceptable concentrations (MAC) of trace metals in agricultural soils suggested by most countries (Kabata-Pendias and Pendias, 1997).

\subsection{Effects of Contamination on Shoot Dry Matter Yields and Evapotranspiration}

Contamination of the soils affected shoot dry matter yield for wheat columns (Table 2), where yields significantly $(\mathrm{p}<0.05$ ) decreased by $55 \%$ in contaminated soil. Accordingly, Kastori et al. (1992), Clijsters et al. (1999), and Veselov et al. (2003) reported low photosynthetic efficiency in heavy metal contaminated soil for sunflower, higher plants and wheat seedling, respectively. On the other hand, safflower yield was not affected by contamination.

During the experiment, each soil column received a total of $588 \mathrm{~mm}$ of water. On average, about $35 \%$ of the applied irrigation water was collected as discharge, thus more water was lost by evapotranspiration (ET) than by discharge. The discharge rate varied significantly $(\mathrm{p}<0.05)$ between contaminated and uncontaminated columns. This difference evolved with time as the plants developed and consumed more water during the growing period (Figure 1).

Wheat and safflower are reported to have similar water consumption in the literature (Doorenbos and Pruitt, 1997), which was also found in this study for uncontaminated columns (Table 2). However, under HM stress there was a significant difference $(\mathrm{p}<0.05)$ in water uptake behavior between the test crops. The wheat plants showed a $12 \%$ decrease in ET in contaminated columns as compared to the uncontaminated ones, while the decrease for safflower was $6 \%$. The effects of HM contamination on decreasing evapotranspiration (which in our study was more obvious for contaminated wheat columns) have been reported by Sheoran et al. (1990) and Kastori et al. (1992). 


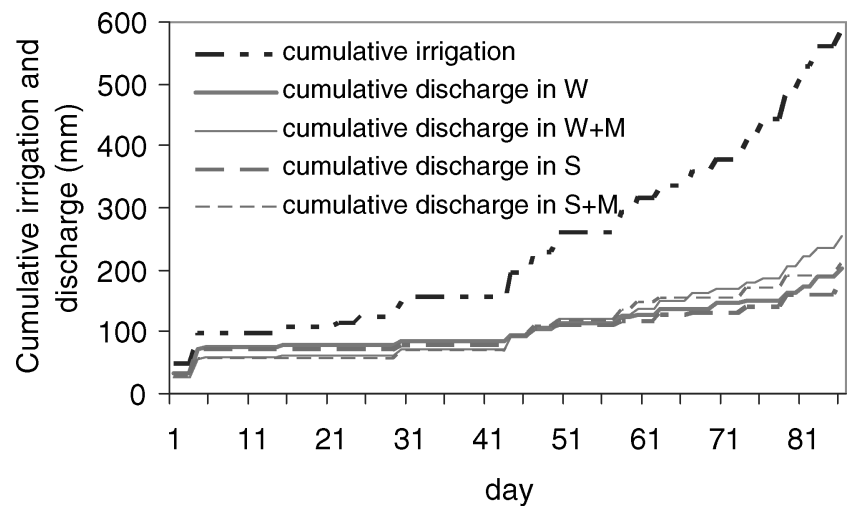

Figure 1. Cumulative irrigation and discharge for different treatments.

However, the decrease in wheat yield (55\%) was substantially greater than the decrease in ET (12\%), which suggests that the water use efficiency of the wheat in the contaminated columns was severely diminished (49\%) while safflower was not affected (2\%). Indeed, normalizing the water use (i.e. ET) to the actual dry matter yield for each treatment indicates that uncontaminated wheat and all safflower treatments had similar normalized water uses of about $13 \mathrm{~mm} \mathrm{H}_{2} \mathrm{O}$ per $\mathrm{g}$ dry weight; in contrast, the contaminated wheat normalized water use was much less efficient at over $27 \mathrm{~mm}$ per g dry weight (Table 2).

\subsection{Plant Metal Concentration}

3.3.1. Effect of contamination on metal accumulation and concentration in different plant tissues. Contamination of topsoil significantly $(\mathrm{p}<0.05)$ increased the accumulation of all four metals $(\mathrm{Cd}, \mathrm{Cu}, \mathrm{Pb}$, and $\mathrm{Zn}$ ) by both plants (Table 3). The increases of metal accumulation in aerial safflower parts in contaminated columns were more than wheat. The order of metal accumulation by both plants was $\mathrm{Zn}>\mathrm{Cu}>\mathrm{Pb}>\mathrm{Cd}$, except for safflower in contaminated columns, which absorbed more $\mathrm{Cd}$ than $\mathrm{Pb}$. Possible reasons for more $\mathrm{Cd}$ uptake in safflower could be due to natural differences between plant species and genotypes. More research is needed to clarify the reasons.

Metals concentrations in different parts of the plants were different, depending on the plant and metal types (Table 4). Both in wheat and safflower the highest metal concentrations

Table 3

Metal accumulation by aerial plant parts (mg/column)*

\begin{tabular}{llllc}
\hline Treatment & \multicolumn{1}{c}{$\mathrm{Cd}$} & $\mathrm{Cu}$ & $\mathrm{Pb}$ & $\mathrm{Zn}$ \\
\hline $\mathrm{W}^{\dagger}$ & $0.001 \pm 0.000^{c \dagger \dagger}$ & $0.056 \pm 0.08^{d}$ & $0.003 \pm 0.001^{c}$ & $0.575 \pm 0.105^{c}$ \\
$\mathrm{~W}+\mathrm{M}$ & $0.008 \pm 0.003^{b}$ & $0.106 \pm 0.028^{c}$ & $0.009 \pm 0.002^{a b}$ & $1.225 \pm 0.414^{b}$ \\
$\mathrm{~S}$ & $0.001 \pm 0.000^{c}$ & $0.346 \pm 0.007^{b}$ & $0.007 \pm 0.001^{b c}$ & $1.383 \pm 0.165^{b}$ \\
$\mathrm{~S}+\mathrm{M}$ & $0.046 \pm 0.059^{a}$ & $0.453 \pm 0.063^{a}$ & $0.012 \pm 0.005^{a}$ & $2.215 \pm 0.768^{a}$ \\
\hline
\end{tabular}

*Average of three replications \pm standard deviation

${ }^{\dagger} \mathrm{W}$ : uncontaminated wheat, $\mathrm{W}+\mathrm{M}$ : contaminated wheat, $\mathrm{S}$ : uncontaminated safflower, $\mathrm{S}+\mathrm{M}$ : contaminated safflower

${ }^{\dagger \dagger}$ In each column means with similar letters (a, b, c, d) are not significantly different at 0.05 level according LSD test. 
were measured in roots. The metal concentrations in roots increased in the order of $\mathrm{Zn}>\mathrm{Cu}>$ $\mathrm{Cd}>\mathrm{Pb}$ in both plants. Root metal concentrations (except for $\mathrm{Pb}$ and $\mathrm{Cd}$ ) in the safflower were greater than wheat. The same trend was observed for shoot metal concentrations in both plants so that in contaminated soil, metal concentrations in safflower shoots were significantly $(\mathrm{p}<0.05)$ more than wheat, except for $\mathrm{Cd}$ and $\mathrm{Pb} . \mathrm{Pb}$ concentration in safflower shoots was significantly $(\mathrm{p}<0.05)$ less than wheat.

Both in contaminated and uncontaminated treatments, head $\mathrm{Zn}$ concentrations in wheat were significantly $(\mathrm{p}<0.05)$ greater (about 1.7 times) than safflower. However, in the case of $\mathrm{Cu}$, concentrations in the head of safflower were 2.5 times those of wheat (significant $(\mathrm{p}<0.05))$. Lubben and Sauerbeck (1991), who used a pot experiment to study metal distribution in spring wheat cultivated in two contaminated soils $\mathrm{pH} 6.5$ Luvisol and $\mathrm{pH}$ $5.5 \mathrm{Cambisol}$ ), found metal concentrations in roots were greater than the aerial parts. They found $\mathrm{Cd}, \mathrm{Zn}, \mathrm{Pb}$ and $\mathrm{Cr}$ contents of the grain to be appreciably lower than those of straw, and in all treatments grain $\mathrm{Zn}$ concentration were greater than $\mathrm{Cu}$, attributed to known $\mathrm{Zn}$ enrichment in the bran. They also found that liming decreased the $\mathrm{Cd}-, \mathrm{Zn}$-, and Ni-content in the plant.

The difference in $\mathrm{Zn}$ and $\mathrm{Cu}$ accumulation in the heads of wheat and safflower probably related to the physiological behavior of these two plants (wheat being a monocotyledon and safflower a dicotyledon), and metals partitioning in the plants can differ. Metal translocation from roots to shoots was differently affected by contamination in safflower and wheat (Table 5): contamination treatment decreased metal translocation from roots to shoots of wheat; however, it had a different effect on safflower. In contaminated safflower treatment, while shoot to root ratios for $\mathrm{Cd}$ and $\mathrm{Zn}$ were significantly greater than control, they did not change for $\mathrm{Cu}$ and $\mathrm{Pb}$ (Table 5).

Table 4

Heavy metal concentrations in different plant tissues ( $\mathrm{mg} \mathrm{kg}^{-1}$ dry weight)*

\begin{tabular}{lccccc}
\hline Treat & Tissue & $\mathrm{Cd}$ & $\mathrm{Cu}$ & $\mathrm{Pb}$ & $\mathrm{Zn}$ \\
\hline $\mathrm{W}^{\dagger}$ & Root & $4.0 \pm 2.8^{b(b) \dagger \dagger}$ & $57.0 \pm 3.7^{d(d)}$ & $3.9 \pm 0.2^{c(b)}$ & $535.8 \pm 63.2^{d(d)}$ \\
$\mathrm{W}$ & Shoot & $0.05 \pm 0.0^{b(b)}$ & $3.6 \pm 0.3^{((d)}$ & $0.3 \pm 0.0^{d(b)}$ & $31.3 \pm 7.8^{e(c)}$ \\
$\mathrm{W}$ & Head & $0.03 \pm 0.0^{b(c)}$ & $5.1 \pm 0.6^{e(d)}$ & $0.2 \pm 0.04^{d(a b)}$ & $60.9 \pm 18.9^{e(b)}$ \\
$\mathrm{W}+\mathrm{M}$ & Root & $50.3 \pm 7.9^{a(a)}$ & $111.7 \pm 19.2^{c(c)}$ & $17.5 \pm 6.1^{a(a)}$ & $1573.5 \pm 99.8^{b(b)}$ \\
$\mathrm{W}+\mathrm{M}$ & Shoot & $0.9 \pm 0.2^{b(a)}$ & $6.4 \pm 0.5^{(c)}$ & $0.9 \pm 0.3^{d(a)}$ & $66.3 \pm 3.0^{e(b)}$ \\
$\mathrm{W}+\mathrm{M}$ & Head & $0.4 \pm 0.07^{b(a)}$ & $6.4 \pm 0.7^{e(c)}$ & $0.2 \pm 0.0^{d(b)}$ & $78.9 \pm 3.1^{e(a)}$ \\
$\mathrm{S}$ & Root & $3.7 \pm 0.3^{b(b)}$ & $161.5 \pm 7.4^{b(b)}$ & $5.9 \pm 1.6^{b(b)}$ & $1086.2 \pm 174.3^{c(c)}$ \\
$\mathrm{S}$ & Shoot & $0.06 \pm 0.01^{b(b)}$ & $9.3 \pm 1.6^{(b)}$ & $0.3 \pm 0.1^{d(b)}$ & $57.7 \pm 0.5^{e(b c)}$ \\
$\mathrm{S}$ & Head & $0.03 \pm 0.01^{b(c)}$ & $13.9 \pm 1.2^{e(b)}$ & $0.1 \pm 0.0^{d(b)}$ & $35.2 \pm 7.7^{e(c)}$ \\
$\mathrm{S}+\mathrm{M}$ & Root & $53.2 \pm 8.9^{a(a)}$ & $255.7 \pm 41.4^{a(a)}$ & $7.1 \pm 0.5^{b(b)}$ & $2514.2 \pm 175.2^{a(a)}$ \\
$\mathrm{S}+\mathrm{M}$ & Shoot & $0.8 \pm 0.1^{b(a)}$ & $17.5 \pm 0.4^{(a)}$ & $0.4 \pm 0.1^{d(b)}$ & $107.8 \pm 31.2^{e(a)}$ \\
$\mathrm{S}+\mathrm{M}$ & Head & $0.3 \pm 0.06^{b(b)}$ & $16.4 \pm 0.6^{e(a)}$ & $0.3 \pm 0.1^{d(a)}$ & $47.5 \pm 10.0^{e(c)}$ \\
\hline
\end{tabular}

${ }^{*}$ Average of three replications \pm standard deviation.

${ }^{\dagger} \mathrm{W}$ : uncontaminated wheat, $\mathrm{W}+\mathrm{M}$ : contaminated wheat, S: uncontaminated safflower, S+M: contaminated safflower.

${ }^{\dagger \dagger}$ In each column means with similar letters (a, b, c, d) are not significantly different at 0.05 level according LSD test. For each plant tissue in each column, means with similar letters in parentheses ((a), (b), (c), (d)) are not significantly different at 0.05 level according LSD test. 
Table 5

Shoot/root ratio ${ }^{\dagger}$ of heavy metals for safflower and wheat*

\begin{tabular}{lcccc}
\hline & $\mathrm{Cd}$ & $\mathrm{Cu}$ & $\mathrm{Pb}$ & $\mathrm{Zn}$ \\
\hline $\mathrm{W}^{\dagger \dagger}$ & $0.068^{c \S}$ & $0.120^{a}$ & $0.067^{b}$ & $0.014^{b}$ \\
$\mathrm{~W}+\mathrm{M}$ & $0.039^{d}$ & $0.029^{c}$ & $0.027^{c}$ & $0.008^{d}$ \\
$\mathrm{~S}$ & $0.166^{b}$ & $0.099^{b}$ & $0.090^{a}$ & $0.028^{c}$ \\
$\mathrm{~S}+\mathrm{M}$ & $0.233^{a}$ & $0.101^{b}$ & $0.100^{a}$ & $0.042^{a}$ \\
\hline
\end{tabular}

*Average of three replications \pm standard deviation

${ }^{\dagger}$ For ratios calculation, total heavy metal mass in shoots was divided to the total heavy metal mass of the roots.

${ }^{\dagger \dagger} \mathrm{W}$ : uncontaminated wheat, $\mathrm{W}+\mathrm{M}$ : contaminated wheat, S: uncontaminated safflower, S+M: contaminated safflower.

${ }^{\S}$ In each column means with similar letters (a, b, c, d) are not significantly different at 0.05 level according LSD test.

3.3.2. Relationship between $\mathrm{HNO}_{3}$ - and DTPA-extractable metals in soil and plants. The order of metal concentration (by both $\mathrm{HNO}_{3}$ - and DTPA extraction methods) in the soil profiles of the uncontaminated and contaminated treatments was $\mathrm{Zn}>\mathrm{Cu}>\mathrm{Pb}>\mathrm{Cd}$ (Table 6). Artificial contamination of topsoil caused an increase in $\mathrm{HNO}_{3}$ - and DTPAextractable metal concentrations in soil profiles of all the treatments, especially in topsoil (Table 6).

Table 6

Average of soil metal concentrations $\left(\mathrm{HNO}_{3}\right.$-extractable and DTPA-extractable) in different treatments $\left(\mathrm{mg} \mathrm{kg}^{-1}\right.$ dry soil)*

\begin{tabular}{|c|c|c|c|c|c|}
\hline Metal & Treatment & HNO3: $0-10 \mathrm{~cm}$ & HNO3: 0-50 cm & DTPA: $0-10 \mathrm{~cm}$ & DTPA: $0-50 \mathrm{~cm}$ \\
\hline \multirow[t]{4}{*}{$\mathrm{Cd}$} & $\mathrm{W}^{\dagger}$ & $1.3 \pm 0.1^{c \dagger \dagger}$ & $1.3 \pm 0.5^{c}$ & $0.06 \pm 0.02^{c}$ & $0.05 \pm 0.02^{c}$ \\
\hline & $\mathrm{W}+\mathrm{M}$ & $12.7 \pm 1.2^{a}$ & $4.1 \pm 0.2^{a}$ & $2.1 \pm 0.1^{a}$ & $0.5 \pm 0.03^{a}$ \\
\hline & $\mathrm{S}$ & $1.3 \pm 0.3^{c}$ & $1.2 \pm 0.1 \mathrm{c}$ & $0.05 \pm 0.0 \mathrm{c} 1$ & $0.03 \pm 0.01 c$ \\
\hline & $\mathrm{S}+\mathrm{M}$ & $6.4 \pm 1.5^{b}$ & $2.8 \pm 0.4^{b}$ & $1.4 \pm 0.1^{b}$ & $0.4 \pm 0.06^{b}$ \\
\hline \multirow[t]{4}{*}{$\mathrm{Cu}$} & $\mathrm{W}$ & $19.8 \pm 1.8^{c}$ & $19.3 \pm 1.9^{c}$ & $4.0 \pm 0.4^{c}$ & $3.4 \pm 0.4^{c}$ \\
\hline & $\mathrm{W}+\mathrm{M}$ & $594.0 \pm 27.3^{a}$ & $146.7 \pm 9.9^{a}$ & $128.5 \pm 10.1^{a}$ & $29.8 \pm 2.8^{a}$ \\
\hline & $\mathrm{S}$ & $20.9 \pm 2.2^{c}$ & $20.6 \pm 2.7^{c}$ & $3.9 \pm 0.5^{c}$ & $3.1 \pm 0.4^{c}$ \\
\hline & $\mathrm{S}+\mathrm{M}$ & $457.7 \pm 17.8^{b}$ & $119.7 \pm 6.1^{b}$ & $103.5 \pm 6.2^{b}$ & $25.2 \pm 1.7^{b}$ \\
\hline \multirow[t]{4}{*}{$\mathrm{Pb}$} & $\mathrm{W}$ & $15.9 \pm 3.6^{b}$ & $14.8 \pm 0.6^{b}$ & $0.9 \pm 0.1^{c}$ & $0.5 \pm 0.1^{c}$ \\
\hline & $\mathrm{W}+\mathrm{M}$ & $109.7 \pm 20.3^{a}$ & $36.4 \pm 4.0^{a}$ & $18.0 \pm 2.1^{b}$ & $4.4 \pm 0.4^{b}$ \\
\hline & $\mathrm{S}$ & $13.1 \pm 2.3^{b}$ & $13.4 \pm 1.3^{b}$ & $0.5 \pm 0.1^{c}$ & $0.4 \pm 0.1^{c}$ \\
\hline & $\mathrm{S}+\mathrm{M}$ & $124.6 \pm 16.3^{a}$ & $37.2 \pm 7.7^{a}$ & $24.5 \pm 2.2^{a}$ & $5.8 \pm 0.6^{a}$ \\
\hline \multirow[t]{4}{*}{$\mathrm{Zn}$} & $\mathrm{W}$ & $67.7 \pm 3.6^{c}$ & $43.8 \pm 6.4^{b}$ & $11.1 \pm 1.0^{c}$ & $3.8 \pm 0.5^{c}$ \\
\hline & $\mathrm{W}+\mathrm{M}$ & $775.0 \pm 14.3^{a}$ & $207.5 \pm 7.6^{a}$ & $161.33 \pm 5.0^{a}$ & $36.7 \pm 1.1^{a}$ \\
\hline & S & $60.6 \pm 1.7^{c}$ & $37.1 \pm 3.4^{c}$ & $7.5 \pm 0.6^{c}$ & $3.0 \pm 0.4^{c}$ \\
\hline & $\mathrm{S}+\mathrm{M}$ & $713.7 \pm 3.5^{b}$ & $208.4 \pm 5.4^{a}$ & $129.8 \pm 8.8^{b}$ & $31.7 \pm 2.1^{b}$ \\
\hline
\end{tabular}

*Average of three replications \pm standard deviation

${ }^{\dagger} \mathrm{W}$ : uncontaminated wheat, $\mathrm{W}+\mathrm{M}$ : contaminated wheat, $\mathrm{S}$ : uncontaminated safflower, $\mathrm{S}+\mathrm{M}$ : contaminated safflower

${ }^{\dagger \dagger}$ For each metal in a column, means with similar letters (a, b, c, d) are not significantly different at 0.05 level according LSD test. 


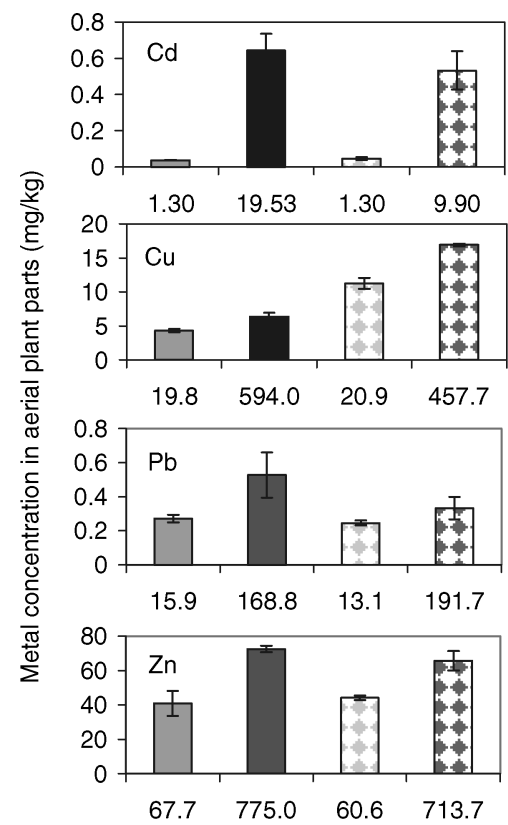

HNO3-extractable metal concentration in topsoil $(\mathrm{mg} / \mathrm{kg})$
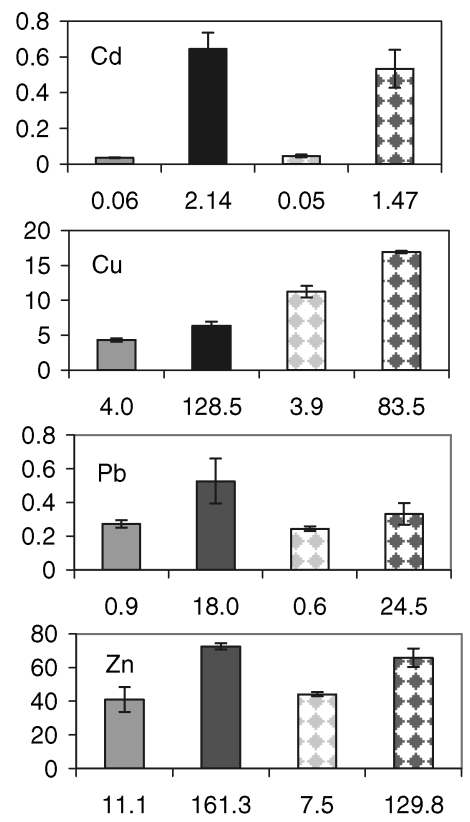

DTPA-extractable metal concentration in topsoil $(\mathrm{mg} / \mathrm{kg})$

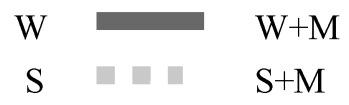

Figure 2. Relationships between $\mathrm{HNO}_{3}$ - and DTPA-extractable metal concentrations in topsoil and metal concentrations in aerial plant parts.

Artificial contamination increased the final $\mathrm{HNO}_{3}$ - and DTPA-extractable Cd of topsoil 10- and 35-fold, respectively, in wheat planted columns. As a result, Cd concentration in aerial wheat parts increased 16-fold (Figure 2). In safflower planted columns, artificial Cd application increased top soil's $\mathrm{HNO}_{3}$-extractable $\mathrm{Cd}$ by a factor of 5, and DTPA-extractable $\mathrm{Cd}$ by a factor of 28. This, in turn, increased Cd concentration in safflower aerial parts by a factor of 12 (Figure 2). This shows wheat has more potential for $\mathrm{Cd}$ accumulation in this type of soil than safflower. In average 31-fold and 24-fold increases in $\mathrm{Cu}$ concentrations of topsoil in wheat and safflower planted columns caused, respectively, 1.5-fold increase in $\mathrm{Cu}$ concentration in aerial plant parts for wheat and safflower (Figure 2). As a result of contaminating soil, $\mathrm{HNO}_{3}$ - and DTPA-extractable $\mathrm{Pb}$ increased in the topsoil of wheat and safflower planted columns, which in turn increased $\mathrm{Pb}$ concentration in aerial wheat by a factor of 2.2 and aerial safflower by a factor of 1.8. As a consequence of artificially applying $\mathrm{Zn}$ in columns, in average, $\mathrm{Zn}$ concentration increased 13.0- and 14.6-fold in the topsoil of wheat and safflower planted columns, respectively, which caused 1.6-fold increase in $\mathrm{Zn}$ concentration in the aerial parts of the both plants (Figure 2).

As the results show, safflower was more tolerant to heavy metal contamination and could produce dry biomass as much as uncontaminated situation with smaller decrease $(6 \%)$ in evapotranspiration than wheat $(12 \%)$. In fact, in our study safflower could grow normally while wheat growth was affected by contamination. One explanation for the differences in the behavior of wheat and safflower could be their rooting systems. Wheat has a fibrous rooting system and most of its growth was limited to the top soil, which was 
the contaminated zone in our study, while safflower has a taproot system, which could more easily escape the contaminated zone. In fact, if not restricted, as in pot experiments, plants try to avoid growing roots in the contaminated zones (Logan and Chaney, 1983; Mench et al., 2000; Rosselli et al., 2003). Many greenhouse studies show a larger metal concentration in aerial plant parts (Vandecasteele et al., 2005), largely because of restricted root growth. The results obtained in this study agree with previous research. Whiting et al. (2001) evaluated the role of $\mathrm{Zn}$ bioavailability in soil on hyperaccumulation by $T$. caerulescens, and concluded that $T$. caerulescens acquired $\mathrm{Zn}$ that was not initially soluble in the soil. They proposed that the high dissolution of insoluble $\mathrm{Zn}$ may have been due to high root density in the soil, as a consequence of the limited volume of pot experiments. The physical restriction of roots in small volumes of soil causes overlapping of the rhizospheres, which increases the root-soil interaction (Marschner, 1995). Consequently, high root density intensifies the effects of weak root-derived mobilization mechanisms, increases microbial density/activity within the soil, and also enhances the dissolution of buffered-Zn by more rapid depletion of the soluble pool due to plant uptake.

One obvious real-world application of our finding would be to select the right kind of crop, based on the soil metals profile. If the contamination is mostly on the top of the profile, avoid fibrous shallow-rooted crops. If it's an older site where most of the metals have started to leach or have leached out of the upper profile, then a shallow fibrous root crop might be better suited than a deep-rooted one. Also, more tolerant crops should be selected for contaminated soils.

\section{Conclusions}

Contamination of the soils decreased significantly the shoot dry matter yield for wheat, while it had no effect on safflower plants. While water use efficiency diminished significantly as a result of metal accumulation in wheat plants, it was not changed significantly in contaminated safflower columns. The increases of metal accumulation in aerial safflower parts in contaminated columns were more than wheat. Also, shoot/root metal ratios were differently affected for wheat and safflower by metals contamination so that contamination treatment decreased metal translocation from roots to shoots of wheat, while it had a different effect on safflower. In contaminated safflower treatment, while shoot to root ratios for $\mathrm{Cd}$ and $\mathrm{Zn}$ were significantly greater than the control, they did not change for $\mathrm{Cu}$ and $\mathrm{Pb}$.

\section{References}

Amini, M., Afyuni, M., Fathianpour, N., Khademi, H., and Fluhler, H. 2005. Continuous soil pollution using fuzzy logic and spatial interpolations. Geoderma. 124, 223-233.

Aoyama, M. and Kuroyanagi, S. 1996. Effects of heavy metal accumulation associated with pesticide application on the decomposition of cellulose and orchard grass in soil. Soil Sci. and Plant Nut. 42, 121-131.

Bassil, E.S. and Kaffka, S.R. 2002. Response of safflower (Carthamus tinctorius L.) to saline soils and irrigation I. Consumptive water use. Agri. Water Manag. 54, 67-80.

Blake, G.R. and Hartge, K.H. 1986. Bulk density. In Methods of Soil Analysis, Part 1, 2nd ed, pp. 363-375 (Klute, A., ed.), American Society of Agronomy, Madison, WI.

Cao, H., Chang, A.C., and Page, A.L. 1984. Heavy metal contents of sludge-treated soils as determined by three extraction procedures. J Environ. Qual. 13, 632-634. 
Clijsters, H., Cuypress, A., and Vangronsveld, J. 1999. Physiological responses to heavy metals in higher plants: defense against oxidative stress. J. of Biosci. 54, 730-734.

Doorenbos, J. and Pruitt, W.O. 1977. Crop Water Requirements. FAO Irrigation and Drainage Paper No. 24, United Nations Food and Agriculture Organization, Rome.

Ewais, E.A. 1997. Effects of cadmium, nickel and lead on growth, chlorophyll content and proteins of weeds. Biologica Plantarum 39, 403-410.

Frost, H.L. and Ketchum Jr., L.H. 2000. Trace metal concentration in durum wheat from application of sewage sludge and commercial fertilizer. Adv. in Environ. Res. 4, 347-355.

Gee, G.W. and Bauder, J.W. 1986. Particle size analysis. In Methods of Soil Analysis, Part 1, 2nd ed, pp. 383-411 (Klute, A., ed.), American Society of Agronomy, Madison, WI.

Gerard, E., Echevarria, G., Sterckeman, T., and Morel, J.L. 2000. Cadmium availability to three plant species varying in cadmium accumulation pattern. J. Environ. Qual. 29, 1117-1123.

Higgins, A.J. 1984. Land application of sewage sludge with regard to cropping system and pollution problems. J. Environ. Qual. 3, 441-448.

Hinz, C. and Selim, H.M. 1994. Transport of zinc and cadmium in soils: experimental evidence and modeling approaches. Soil Sci. Soc. Am. J. 58, 1316-1327.

Hooda, P.S. and Alloway, B.J. 1994. The plant availability and DTPA extractability of trace metals in sludge-amended soils. Sci. Total Environ. 149, 39-51.

Kabata-Pendias, A. and Pendias, H. 1997. Trace Elements in Soils and Plants, CRC Press, Boca Raton, FL.

Kastori, R., Petrovic, M., and Petrovic, N. 1992. Effect of excess lead, cadmium, copper, and zinc on water relations in sunflower. J. Plant Nut. 15 (11), 2427-2439.

Khoshgoftar, A.H., Shariatmadari, H., Karimian, N., Kalbasi, M., van Der Zee, S.E.A.T.M., and Parker, D.R. 2004. Salinity and zinc application effects on phytoavailability of cadmium and zinc. Soil Sci. Soc. Am. J. 68, 1885-1889.

Klute, A. 1986. Water retention: laboratory methods. In Methods of Soil Analysis, Part 1, 2nd ed., pp. 635-662 (Klute, A., ed.), American Society of Agronomy, Madison, WI.

Li, L. and Li, F. 2001. Heavy metal sorption and hydraulic conductivity studies using three types of bentonite admixes. J. Environ. Eng. 127, 420-429.

Liu, J., Li, K., Xu, J., Liang, J., Lu, X., Yang, J., and Zhu, Q. 2003. Interaction of Cd and five mineral nutrients for uptake and accumulation in different rice cultivars and genotypes. Field Crops Res. 83, 271-281.

Logan, T.J. and Chaney, R.L. 1983. Utilisation of municipal wastewater and sludge on land-metals. In Proc. of the 1983 Workshop on Utilisation of Municipal Wastewater and Sludge on Land, pp. 235-326 (Page, A.L., Gleason III, T.L., Smith, J.E., I.K. Iskandar, Jr., and Sommers, L.E., eds.), Univ. of California, Riverside, CA.

Lubben, S. and Sauerbeck, D. 1991. The uptake and distribution of heavy metals by spring wheat. Water Air Soil Pollut. 57-58, 239-247.

Marschner, H. 1995. Mineral Nutrition of Higher Plants, Academic Press Limited, London.

McBride, M.B., Richards, B.K., Steenhuis, T., Russo, J.J., and Sauvé, S. 1997. Mobility and solubility of toxic metals and nutrients in soil fifteen years after sludge application. Soil Sci. 162, 487-500.

Mench, M.J., Manceau, A., Vangronsveld, J., Clijsters, H., and Mocquot, B. 2000. Capacity of soil amendments in lowering the phytoavailability of sludge-borne zinc. Agro. 20, 383-397.

Obrador, A., Novillo, J., and Alvarez, J.M. 2003. Mobility and availability to plants of two zinc sources applied to a calcareous soil. Soil Sci. Soc. Am. J. 67, 564-572.

Plassard, F., Winiarski, T., and Petit-Ramel, M. 2000. Retention and distribution of three heavy metals in a carbonated soil: comparison between batch and unsaturated column studies. J. Contamin. Hyd. 42, 99-111.

Prasad, M.N.V. 1995. Inhibition of maize leaf chlorophylls, carotenoids and gas exchange functions by cadmium. Photosynthetica 31, 635-640.

Richards, B.K., Steenhuis, T.S., Peverly, J.H., and McBride, M.B. 1998. Metal mobility at an old, heavily loaded sludge application site. Environ. Pollut. 99, 365-377. 
Rosselli, W., Keller, C., and Boschi, K. 2003. Phytoextraction capacity of trees growing on a metal contaminated soil. Plant Soil 256, 265-272.

Santa-Maria, G.E., and Cogliatti, D.H. 1998. The regulation of zinc uptake in wheat plants. Plant Sci. 137, 1-12.

Schmidt. U. 2003. Enhancing phytoextraction: The effect of chemical soil manipulation on mobility, plant accumulation, and leaching of heavy metals. J. Environ. Qual. 32, 1939-1954.

Schwab, A.P., Banks, M.K., and Erickson, L.E. 2002. Fate and transport of heavy metals and radionuclides in soil: The impact of vegetation. Kansas State University, http//www.engg.ksu.edu/HSRC/fate.html/.

Sheoran, I.S., Aggarwal, N., and Singh, R. 1990. Effect of cadmium and nickel on in vivo carbondioxide exchange rate of pigeon pea (Cajanus-Cajan L). Plant Soil 129, 243-249.

Smolders, E. and McLaughlin, M.J. 1996. Chloride increases cadmium uptake in Swiss chard in a resin-buffered nutrient solution. Soil Sci. Soc. Am. J. 60, 1443-1447.

Soil Survey Staff. 2003. Keys to Soil Taxonomy, United States Department of Agriculture, Natural Resources Conservation Service, 9th edition, Washington D.C., pp. 103-127.

Soltanpour, P.N. 1991. Determination of nutrient availability and element toxicity by AB-DTPA soil test and ICPS. Adv. Soil Sci. 16, 165-190.

Sposito, G., Lund, L., and Chang, A. 1981. Trace metal chemistry in arid-zone field soils amended with sewage sludge: I. Fractionation of $\mathrm{Ni}, \mathrm{Cu}, \mathrm{Zn}, \mathrm{Cd}$ and $\mathrm{Pb}$ in solid phases. Soil Sci. Soc. Am. J. 46, 260-264.

Street, J.J., Lindsay, W.L., and Sabey, B.R. 1977. Solubility and plant uptake of cadmium in soils amended with cadmium and sewage sludge. J. Environ. Qual. 6 (1), 72-77.

Sumner, M.E. and Miller, W.P. 1996. Cation exchange capacity and exchange coefficients. In: Methods of Soil Analysis. Part 2, pp. 1201-1229, (Sparks, D.L., ed.), America Society of Agronomy, Madison, WI.

USEPA. 1993. Clean Water Act, United States Environmental Protection Agency Publication, Section 503, Vol. 58, No. 32, Washington, DC.

van Assche, F. and Clijsters, H. 1988. Induction of enzyme capacity in plants as a result of heavy metal toxicity: Dose-response relation of Phaseolus vulgaris $L$ treated with zinc and cadmium. Environ. Pollut. 52, 103-115.

van Lune, P. and Zwart, K.B. 1997. Cadmium uptake by crops from the subsoil. Plant Soil 189, 231-237.

Vandecasteele, B., Meers, E., Vervaeke, P., De Vos, B., Quataert, P., and Tack, F.M.G. 2005. Growth and trace metal accumulation of two Salix clones on sediment-derived soils with increasing contamination levels. Chemosphere 58, 995-1002.

Veselov, D., Kudoyarova, G., Symonyan, M., and Veselov, St. 2003. Effect of cadmium on ion uptake, transpiration and cytokinin and cytokinin content in wheat seedling. Bulg. J. Plant Physol., Special Issue, 353-359.

Wagner, G.L. 1993. Accumulation of cadmium in crop plants and its consequences to human health. Adv. Agron. 51, 173-212.

Walkley, A. and Black, C.A. 1934. An examination of the Degtareff method for determining soil organic matter and a proposed modification of the chromic acid titration. Methods in Soil Sci. 37, 29-38.

Walter, I., Martinez, F., Alonso, L., de Gracia, J., and Cuevas, G. 2002. Extractable soil heavy metals following the cessation of biosolids application to agricultural soil. Environ. Pollut. 117, $315-321$.

Water Resource Characterization DS-Heavy Metals (WRCD). 1996. Heavy metals. http:// h2osparc.wq.ncsu.edu/info/hmetals.html, pp. 1-10.

Wierzbicka, M. and Obidzinska, J. 1998. The effect of lead on seed imbibition and germination in different plant species. Plant Sci. 137, 155-171.

Whiting, S.N., Leake, J.R., McGrath, S. P., and Baker, A.J.M. 2001. Zinc accumulation by Thlaspi caerulescens from soils with different Zn availability: a pot study. Plant Soil 236, 11-18. 